\title{
MODULASI SEL PUNCA MESENKIMAL DALAM MENURUNKAN KADAR HIGH SENSITIVITY C-REACTIVE PROTEIN SEBAGAI TERAPI NEFRITIS LUPUS
}

\author{
MESENCHYMAL STEM CELLS MODULATION IN REDUCING HIGH SENSITIVIY \\ OF C-REACTIVE PROTEIN LEVEL AS LUPUS NEPHRITIS THERAPY
}

\author{
Indah Putri Maharani, Zainal Arifin Adnan, Arifin, Arief Nurudhin \\ Sub Bagian Rheumatologi, Bagian Ilmu Penyakit Dalam \\ FK UNS / RSUD Dr. Moewardi Surakarta \\ Korespondensi: Indah Putri Maharani: sonyranisofi@gmail.com
}

\begin{abstract}
ABSTRAK
Systemic Lupus Erythematosus merupakan penyakit inflamasi autoimun kronis dengan gambaran klinis luas dan perjalanan penyakit beragam. Pemberian pristan intraperitoneal dapat menginduksi lupus pada mencit. Secretome sel punca mesenkimal bekerja secara parakrin memberikan efek antinflamasi dan imunomodulasi antara lain mensupresi sel T dan sel B autoreaktif. High Sensitivity C-Reactive Protein (hsCRP) terkait dengan patogenesis SLE dan selaras dengan aktifitas penyakit.Tujuan Penelitian adalah untuk mengetahui pengaruh secretome sel punca mesenkimal terhadap kadar hsCRP pada mencit model lupus dengan induksi pristan. Desain penelitian adalah eksperimental dengan randomisasi, post test only control group design, sampel 21 ekor mencit betina Mus Musculus galur Balb/C, dibagi 3 kelompok yaitu kelompok kontrol (injeksi intraperitoneal NaCl 0,9\% $0,5 \mathrm{ml}$ ), kelompok perlakuan (injeksi pristan intraperitoneal 0,5 $\mathrm{ml}$ ) dan kelompok terapi (injeksi intraperitoneal pristan 0,5 $\mathrm{ml}$ dan secretome 0,45 ml). Penelitian dilakukan selama 3 minggu, secretome diberikan pada akhir penelitian. Sesudah perlakuan dinilai kadar hsCRP secara ELISA. Analisis statistik menggunakan SPSS 22 for windows dengan uji Kruskal-Wallis dilanjutkan Mann-Whitney U test. P bermakna jika $p<0,05$. Hasil penelitian menunjukkan bahwa rata-rata kadar hsCRP pada ketiga kelompok yaitu kontrol 440.68(110.08-564.29) ng/ $\mathrm{mL}$; perlakuan (pristan) 2964.26(601.13-3926.10) $\mathrm{ng} / \mathrm{mL}$; terapi (pristan+secretome) 506.93(207.62-1473.46) $n g / m L$, dengan kemaknaan $p=0.008$. Terdapat perbedaan bermakna kadar hsCRP antara kelompok pristan vs pristan+secretome $(2457.33 \mathrm{ng} / \mathrm{mL} ; \mathrm{p}=0.047)$. Secretome sel punca mesenkimal mampu menurunkan kadar hsCRP pada mencit model lupus dengan induksi pristan.
\end{abstract}

Kata Kunci: High Sensitivity C-Reactive Protein, Nefritis lupus, Secretome

\section{ABSTRACT}

Systemic Lupus Erythematosus is a chronic autoimmune inflammatory disease with clinical presentation and course of the disease vary widely. Giving Pristan intraperitoneally to induce lupus in mice. Secretome mesenchymal stem cells work in a paracrine effect and immunomodulating antinflamasi include suppression of $T$ cells and $B$ cells are autoreactive. High Sensitivity C-Reactive Protein (hSCRP) associated with the pathogenesis of SLE and aligned with penyakit.Tujuan research activity is to determine the effect of mesenchymal stem cell secretome on hsCRP levels in mice with induced lupus models Pristan. The study design is a randomized experimental, post test only control group design, sample 21 female mice Mus musculus strain Balb / C, divided into 3 groups: control group (intraperitoneal injection of $0.5 \mathrm{ml} 0.9 \% \mathrm{NaCl}$ ), the treatment group (injection Pristan intraperitoneal 0.5 $\mathrm{ml}$ ) and the treatment group (intraperitoneal injection of $0.5 \mathrm{ml}$ Pristan and secretome $0.45 \mathrm{ml}$ ). Research carried out for 3 weeks, secretome given at the end of the study. HsCRP levels after treatment rated by ELISA. Statistical analysis using SPSS 22 for windows with the Kruskal-Wallis test followed Mann-Whitney U test. P significant if $p$ $<0.05$. Results showed that the median hsCRP levels in all three groups: control 440.68 (110.08-564.29) $\mathrm{ng} / \mathrm{mL}$; treatment (Pristan) 2964.26 (601.13-3926.10) $\mathrm{ng} / \mathrm{mL}$; therapy (Pristan + secretome) 506.93 (207.62-1473.46) 
$n g / m L$, with significance $p=0.008$. There are significant differences between the groups hsCRP levels vs Pristan Pristan + secretome (2457.33 $\mathrm{ng} / \mathrm{mL} ; \mathrm{p}=0.047)$. Mesenchymal stem cells Secretome can reduce of hsCRP levels in mice with induced lupus models Pristan.

Keywords: High Sensitivity C-Reactive Protein, Nefritis lupus, Secretome

\section{PENDAHULUAN}

Systemic Lupus Erythematosus (SLE) adalah penyakit inflamasi autoimun kronis yang belum jelas penyebabnya dengan gambaran klinis yang luas serta tampilan perjalanan penyakit beragam (Perhimpunan Reumatologi Indonesia, 2011). Etiopatologi SLE melibatkan interaksi yang kompleks dan multifaktorial antara variasi genetik dan faktor lingkungan. Gangguan dalam mekanisme pengaturan imun seperti gangguan pembersihan sel-sel apoptosis dan kompleks imun berperan penting dalam perkembangan penyakit ini. Hilangnya toleransi imun, meningkatnya beban antigenik, bantuan sel $\mathrm{T}$ yang berlebihan, gangguan supresi sel $\mathrm{B}$ dan peralihan respons imun dari Thelper 1 (Th1) ke Th2 menyebabkan hiperaktivitas sel B sehingga terbentuk autoantibodi patogenik. Respons imun akibat paparan faktor eksternal/lingkungan seperti radiasi ultraviolet dalam periode yang cukup lama dapat menyebabkan disregulasi sistem imun (Suarjana, 2014). Sitokin juga berperan sebagai kunci utama dalam imunopatogenesis SLE. Sitokin merupakan faktor terlarut yang berperan penting dalam diferensiasi, maturasi dan aktivasi berbagai sel-sel imun serta menimbulkan respon inflamasi lokal yang menyebabkan kerusakan jaringan. Sitokin tertentu seperti IL-6, IL-10, IL-17, BLys, IFN type 1, dan $\mathrm{TNF} \alpha$ sangat terkait dengan patogenesis SLE (Yap dan Lai, 2010). Sel B adalah kunci untuk aktivasi sistem imun terutama melalui sitokin dan sebagai antigen presenting cell/ APC (Postal et al., 2012). Identifikasi biomarker yang terkait erat dengan aktivitas penyakit SLE menjadi sebuah kebutuhan. Pasien SLE memiliki kadar IL-6, IL-10, IL-12, dan IFN $\gamma$ yang tinggi. Serum IL-6 signifikan meningkat pada pasien SLE aktif dan berkorelasi dengan indeks aktivitas SLE (SLEDAI), tingkat sedimentasi eritrosit (ESR), dan $C$-reactive protein (CRP). Serum IL10 signifikan meningkat pada pasien SLE aktif dan berkorelasi positif dengan SLEDAI dan antidsDNA, sehingga IL-10 dapat menjadi biomarker aktivitas penyakit SLE (Chun et al., 2007). High sensitivity CRP (hsCRP) merupakan teknik untuk mendeteksi CRP dengan kadar lebih rendah daripada yang dapat dideteksi dengan metode konvensional (Rezaieyasdi et al., 2011). Kadar hsCRP signifikan lebih tinggi pada pasien SLE dengan kerusakan organ dibandingkan pasien SLE tanpa kerusakan organ, dimana nilai median hsCRP pada kedua kelompok $<0.5 \mathrm{mg} / \mathrm{dl}$ (Firooz et al., 2011).

Pristan atau tetramethylpentadecane (TMPD) merupakan alkalin isoprenoid (minyak hidrokarbon alami) yang didapatkan dari berbagai tanaman yang dapat memicu inflamasi kronik ketika dipaparkan ke dalam kavum peritoneal. Respon inflamasi tersebut menyebabkan SLE pada mencit (Reeves et al., 2009). Pemberian pristan pada mencit BALB/c memicu autoantibodi sebagai karakteristik lupus. Mencit yang terpapar pristan juga memiliki deposit komplek imun di ginjal yang menyebabkan proteiuria berat dan nefritis (Perry et al., 2010). Mencit BALB/c yang diberikan injeksi pristan mengalami glomerulonefritis yang tidak terlalu berat (proteinuria +3 sampai +4 dan perubahan proliferatif), artritis, ANA, dan bermacam-macam autoantibodi lupus termasuk anti dsDNA dan anti Sm (Reeves et al., 2009).

Sel punca mesenkimal dewasa adalah sel multipoten yang dapat berdiferensiasi menjadi beberapa tipe sel mesenkimal khusus tahap akhir seperti osteoblas, kondrosit, adiposit, tenosit, dan lain-lain (Meirelles et al., 2009). Sel punca mesenkimal memiliki efek imunomodulasi yang terbukti berpengaruh pada sel limfosit $\mathrm{T}$ dan $\mathrm{B}$, natural killer dan antigen precenting cells (APC). Sel punca mesenkimal bersifat hipoimmunogenik karena hanya sedikit mengekspresikan Major Histocompatibility (MHC) kelas I dan tidak mengekspresikan MHC kelas II atau molekul ko-stimulasi (CD40, CD40L, CD80 atau CD86), sehingga penggunaan sel punca mesenkimal alogenik tidak memerlukan pencocokan dengan Host Leukocyte Antigen/HLAs (Carrion dan Figueroa, 2011).

Berbagai aktivitas sel punca mesenkimal terbukti berasal dari produk yang disekresikan oleh sel-sel tersebut (Madrigal et al, 2014). 
Penelitian oleh Yang (2008) menyebutkan efek secretome sel punca mesenkimal pada tikus model spinal cord injury. Penelitian oleh Song (2014) pada tikus model kandung kemih hiperaktif menunjukkan efek parakrin sel punca mesenkimal. Penelitian oleh Sun (2010) dan Liang (2010) juga menunjukkan perbaikan pada pasien SLE berat yang refrakter. Sel punca mensekresikan sejumlah protein (secretome) termasuk growth factor, kemokin, sitokin, metabolit dan lipid bioaktif yang mengatur secara autokrin atau parakrin sambil merekayasa interaksi dengan lingkungan mikro sekitarnya (Drago et al., 2013).

Terapi yang lebih efektif dengan efek samping lebih ringan dibandingkan dengan yang ditimbulkan oleh sitotoksik dan glukokortikoid hingga saat ini masih dibutuhkan. Penelitian terus dilakukan untuk mencari strategi terapi baru dengan efektivitas lebih tinggi dan komorbiditas lebih rendah (Musai, 2010). Belum ada penelitian sebelumnya yang menggunakan secretome sel punca mesenkimal pada SLE sehingga peneliti ingin meneliti pengaruh secretome sel punca mesenkimal pada kultur medium terkondisi hipoksia terhadap kadar hsCRP pada mencit model lupus dengan induksi pristan.

\section{METODE PENELITIAN}

Penelitian ini menggunakan rancangan penelitian eksperimental dengan metode post test only control group design. Sampel 21 ekor mencit betina sub spesies Mus musculus galur $\mathrm{Balb} / \mathrm{C}$, umur 3-4 bulan, berat badan 20-30 gram, dibagi menjadi 3 kelompok. Kelompok kontrol diberi injeksi $\mathrm{NaCl} 0,9 \% 0,5 \mathrm{ml}$ intraperitoneal, kelompok perlakuan diberi injeksi pristan $0,5 \mathrm{ml}$ intraperitoneal, kelompok terapi diberi injeksi intraperitoneal pristan $0,5 \mathrm{ml}$ dan secretome sel punca mesenkimal $0,45 \mathrm{ml}$ dosis tunggal intraperitoneal. Penelitian dilakukan selama 3 minggu, injeksi secretome intraperitoneal dilakukan pada hari ke 24. Kemudian diperiksa hsCRP secara ELISA. Analisis statistik menggunakan SPSS 22 for windows. Uji beda dua rerata menggunakan uji non parametrik MannWhitney dengan nilai $\mathrm{p}$ bermakna jika $\mathrm{p}<0,05$.

\section{HASIL DAN PEMBAHASAN}

Deskripsi serta hasil uji normalitas data masing-masing kelompok untuk variabel hsCRP sebagai berikut:

Tabel 1. Deskripsi dan uji normalitas variabel hsCRP

\begin{tabular}{lccc}
\hline \multicolumn{1}{c}{ Kelompok } & $\begin{array}{c}{[\text { median(min-max) }} \\
(\mathbf{n g} / \mathbf{m L})\end{array}$ & \multicolumn{2}{c}{ Uji Normalitas } \\
\cline { 3 - 4 } & $440.68(110.08-564.29)$ & 0.937 & 0.612 \\
1. Kontrol & $2964.26(601.13-3926.10)$ & 0.806 & $0.047^{*}$ \\
2. Pristan & $506.93(207.62-1437.46)$ & 0.848 & 0.118 \\
\hline
\end{tabular}

Sumber: Data Primer 2016, diolah. Keterangan : * Signifikan pada derajat signifikansi 5\%.

Mencit yang diberikan perlakuan pristan memiliki rata-rata hsCRP lebih tinggi dibandingkan kelompok kontrol. Rata-rata hsCRP pada kelompok terapi pristan dan secretome lebih rendah dibandingkan kelompok perlakuan pristan namun masih lebih tinggi dibandingkan dengan rata-rata hsCRP pada kelompok kontrol. Sebaran data variabel hsCRP tidak normal $(\mathrm{p}<0,05)$, sehingga selanjutnya digunakan Uji KruskalWallis dilanjutkan Uji Mann-Whitney.

Hasil pengujianKruskal-Wallis untuk variabel hsCRP sebagai berikut: 
Tabel 2. Variasi atau Perbedaan Tiga Rata-rata Variabel hsCRP menurut Kelompok Sampel.

\begin{tabular}{cccccc}
\hline \multicolumn{2}{c}{ Kontrol } & \multicolumn{2}{c}{ Pristan } & \multicolumn{2}{c}{ Pristan + Secretome } \\
\hline Rata-rata & Std & Rata-rata & Std & Rata-rata & Std \\
387.053 & 156.99 & 2152.91 & 1440.92 & 686.33 & 524.90 \\
Chi-Square 9.654 & Asymp sig $=0,008^{* *}$ & \multicolumn{2}{c}{ Signifikan } \\
\hline
\end{tabular}

Sumber: Data Primer 2016, diolah. Keterangan : $\left.{ }^{* *}\right)$ Signifikan pada derajat signifikansi 1 persen.

Rata-rata variabel hsCRP pada kelompok pristan lebih tinggi dibandingkan kelompok kontrol dan kelompok terapi pristan + secretome. Rata-rata variabel hsCRP pada kelompok pritan+secretome lebih tinggi daripada kelompok kontrol. Tabel tersebut menunjukkan p $0.008(\mathrm{p}<0.05)$ yang berarti terdapat perbedaan rata-rata hsCRP yang bermakna di antara kelompok kontrol, perlakuan pristan dan kelompok terapi pristan + secretome.

Hasil penelusuran beda dua rata-rata variabel hsCRP antar kelompok sampel dijelaskan dengan tabel sebagai berikut:

Tabel 3. Penelusuran beda dua rata-rata variabel hsCRP antar kelompok kontrol, pristan, pristan + secretome

\begin{tabular}{lcccc}
\hline Kelompok & $\begin{array}{c}\text { Mann-Whitney } \\
\text { U }\end{array}$ & Wilcoxon W & Z & $\begin{array}{c}\text { Sig. } \\
\text { (2 tailed })\end{array}$ \\
\hline $\begin{array}{l}\text { Kontrol vs Pristan } \\
\text { Pristan vs Pristan }+ \\
\text { secretome }\end{array}$ & 0.000 & 28.000 & -3.130 & $0.002 *$ \\
\hline
\end{tabular}

Sumber: Data Primer 2016, diolah. Keterangan : *) Signifikan pada derajat signifikansi 5 persen.

Uji terhadap variabel hsCRP antara kelompok kontrol dan perlakuan pristan memiliki tingkat signifikansi sebesar 0,002 persen $(\mathrm{p}<$ $0,05)$. Kelompok kontrol memiliki kadar ratarata hsCRP $387.05 \mathrm{ng} / \mathrm{ml}$ sedangkan kelompok pristan memiliki kadar hsCRP rata-rata 2152.92 $\mathrm{ng} / \mathrm{ml}$. Mencit kelompok perlakuan pristan ratarata variabel hsCRP lebih tinggi dibandingkan pada kelompok kontrol. Setelah diberikan pristan dan secretome sel punca mesenkimal maka ratarata variabel hsCRP lebih rendah dibandingkan pada kelompok perlakuan pristan dengan tingkat signifikansi sebesar $0,047(\mathrm{p}<0,05)$. Kelompok pristan + secretome sel punca mesenkimal memiliki kadar hsCRP rata-rata $686.33 \mathrm{ng} /$ $\mathrm{ml}$ yang lebih rendah dibandingkan kelompok pristan namun sedikit lebih tinggi dibandingkan kelompok kontrol.

Pemberian secretome sel punca mesenkimal dapat menurunkan kadar hsCRP pada mencit model lupus dengan induksi pristan. Hal ini dilihat dari pemberian secretome sel punca mesenkimal $0,45 \mathrm{ml}$ dosis tunggal secara injeksi intraperitoneal menurunkan kadar hsCRP pada mencit model lupus dengan induksi pristan yang secara statistik bermakna signifikan dibandingkan dengan kontrol.

Secretome pada penelitian ini diperoleh dari sel punca mesenkimal cairan amnion manusia yang dikondisikan hipoksia $\left(\mathrm{O}_{2}\right.$ 1-2\%). Kondisi hipoksia meningkatkan produksi growth factor dan molekul-molekul antiinflamasi, antara lain FGF, VEGF, IGF, HGF, dan menurunkan proliferasi sel T. Khasiat sel punca mesenkimal terutama disebabkan oleh secretome yang memiliki efek parakrin, terutama efek antiinflamasi dan imunomodulasi. HGF bekerja sebagai imunomodulator, antiinflamasi dan melindungi dari apoptosis. VEGF bekerja sebagai anti apoptosis (Madrigal et al, 2014). Pada SLE terjadi gangguan pembersihan sel-sel apoptosis dan kompleks imun, hilangnya toleransi imun, meningkatnya beban antigenik, bantuan sel $T$ yang berlebihan, gangguan supresi sel B dan peralihan respon imun dari Th1 ke Th2 menyebabkan hiperaktivitas sel B sehingga muncul autoantibodi patogenik (Suarjana, 2014).

Secretome sel punca mesenkimal menghambat proliferasi sel $\mathrm{T}$ yang berlebihan sehingga menekan produksi IL-10 dan 
menghambat hiperaktivitas sel B autoreaktif. Pembentukan autoantibodi ditekan sehingga mencegah penumpukan kompleks imun pada sel mesangial ginjal dan mencegah kerusakan ginjal lebih lanjut (Suarjana, 2014; Madrigal et al, 2014, Meirelles et al, 2009).

Penelitian ini menunjukkan kadar hsCRP pada kelompok perlakuan lebih tinggi daripada kelompok kontrol. Hal ini menunjukkan respon inflamasi hepatosit yang dipicu oleh IL-6 akibat induksi pristan intraperitoneal. Tingginya kadar hsCRP seiring dengan aktifitas penyakit dan derajat kerusakan organ, terutama pada pulmonal, sistem muskuloskeletal dan ginjal (Mok et al, 2013; Lee et al, 2009). Pemberian secretome sel punca mesenkimal pada penelitian ini menurunkan kadar hsCRP dibandingkan kelompok perlakuan pristan walaupun tidak sama dengan kelompok kontrol. Secretome sel punca mesenkimal menghambat aktivasi dan proliferasi sel $\mathrm{T}$ dan sel $\mathrm{B}$ juga menurunkan produksi sitokin antara lain IL-6 sehingga menghambat produksi hsCRP di hati. Hal ini akan mengurangi CRP yang mengikat komplemen dan aktivasi jalur komplemen klasik sehingga mencegah penumpukan kompleks imun pada organ (Mok et al, 2013; Kyurkchiev et al, 2014). HGF yang terdapat dalam secretome menghambat SLE dengan menginhibisi Th2. HGF menekan ekspresi MHC kelas II oleh sel B yang menyebabkan penurunan presentasi antigen kepada sel T CD4 sehingga dapat menekan kejadian lupus nefritis (Kuroiwa et al, 2006). Mekanisme lain adalah menekan sel dendritik, induksi fenotip sel CD4+ yang memproduksi IL10 dan TGF $\beta$ (Okunishi et al, 2007).

Penelitian sebelumnya mengenai efek parakrin secretome dilakukan oleh Gnecchi (2005) pada mencit model penyakit jantung (infark). Sel punca mesenkimal sumsum tulang diinjeksikan pada jantung yang mengalami infark ternyata tidak berdiferensiasi menjadi kardiomiosit dalam kondisi in vivo fisiologis. Sebagian besar sel punca mesenkimal berkumpul di paru-paru dan hati setelah injeksi intravena dan hanya sebagian kecil memasuki jaringan patologis. Gnecchi (2005) menyimpulkan bahwa pengaruh klinis sel punca mesenkimal bukan karena diferensiasi sel, setelah diketahui terdapat perbaikan fungsi jantung dan pencegahan remodelling ventrikel dalam waktu $<72$ jam setelah injeksi. Demikian juga penelitian oleh Lee (2009) pada mencit model infark jantung yang diberikan injeksi intravena sel punca mesenkimal manusia menunjukkan efek antiinflamasi, berkurangnya ukuran infark jantung dan perbaikan fungsi jantung dengan hanya sebagian kecil sel punca yang ada di jaringan patologis.

Sun (2010) melakukan uji klinis pada 16 pasien SLE yang refrakter terhadap terapi standart (siklofosfamid dan prednison oral) atau SLE berat. Pasien diberi sel punca mesenkimal tali pusat manusia secara intravena dengan sebelumnya diberikan siklofosfamid dan sesudahnya diberikan prednison dengan tappering dose. Hasil penelitian tersebut menunjukkan setelah 3 bulan didapatkan perbaikan aktifitas penyakit (skor SLEDAI), perbaikan serologis (ANA, antibodi anti dsDNA, albumin serum, C3, fungsi ginjal) dan stabilnya sitokin proinflamasi (meningkatnya Treg, keseimbangan sitokin terkait Th1-Th2) pada semua pasien. Tidak didapatkan kekambuhan maupun kematian terkait terapi yang diberikan. Pasien yang menderita nefritis lupus juga mengalami perbaikan. Selain itu juga dilaporkan bahwa terapi sel punca mesenkimal berhasil mengurangi gangguan ginjal pada SLE, walaupun penelitian ini menggunakan metode yang belum terkontrol baik (Lee et al, 2010).

Pemberian secretome sel punca mesenkimal dapat dipertimbangkan sebagai salah satu terapi SLE yang potensial. Secretome sel punca mesenkimal lebih aman daripada terapi imunosupresif yang luas digunakan saat ini. yang memiliki berbagai efek samping seperti infeksi, efek toksik kumulatif obat, peningkatan resiko kardiovaskuler dan keganasan. Secretome sel punca mesenkimal bersifat hipoimunogenik dan relatif aman diberikan (Liang et al, 2010; Sun et al, 2010; Carrion et al, 2011).

\section{SIMPULAN}

Pemberian secretome sel punca mesenkimal menurunkan kadar hsCRP pada mencit model lupus dengan induksi pristan. 


\section{DAFTAR PUSTAKA}

Carrion, F.A., Figueroa, F.E. 2011. Mesenchymal Stem Cells for the Treatment of Systemic Lupus Erythematosus: Is the Cure for Connective Tissue Disease Within Connective Tissue?. Stem Cell Research \& Therapy, vol. 2, no. 23, hlm. 1-8.

Chun, H.Y., Chung, J.W., Kim, H.A., Yun, J.M., Jeon, J.Y., Ye, Y.M., Kim, S.H., Park, H.S., Suh, C.H. 2007. Cytokine IL-6 and IL-10 as Biomarkers in Systemic Lupus Erythematosus. Journal of Clinical Immunology, vol. 2007, no. 27, hlm. 461-466.

Drago, D., Cossetti, C., Iraci, N., Gaude, E., Musco, G., Bachi, A., Pluchino, S. 2013. The Stem Cell Secretome and It's Role in Brain Repair. Biochimie, vol. 2013, no. 95, hlm. 2271-2285.

Firooz, N., Albert, D.A., Ishimori, M., Berel, D., Weisman, M.H. 2011. High Sensitivity C Reactive Protein and Erythrocyte Sedimentation Rate in Systemic Lupus Erythematosus. Lupus, vol. 2011, no. 20, hlm. 588-597.

Gnecchi, M., He, H., Liang, O.D., Mello, L.G., Morello, F., Mu, H., Noiseux, N., Zhang, L. Pratt R.E, Ingwall, J.S., Dzau, V.J. 2005. Paracrine Actions Accounts for Marked Protection of Ischemic Heart by Akt-Modified Mesenchymal Stem Cells. Nature Publishing Group, vol. 11, hlm. 367-368.

Kuroiwa, T., Iwasaki, T., Sano, H. 2006. Hepatocyte Growth Factor Prevents Lupus Nephritis in Murine Lupus Model of Chronic Graft-Versus_Host Disease. Arthritis Research and Therapy, vol. 8, no. 4 , hlm. 1-8.

Kyurkchiev, D., Bochev, I., Todorova, E.I., Mourdjeva, M., Oreshkova, T., Belemezova, K., Kyurkchiev, S. Secretion of Immunoregulatory Cytokines by Mesenchymal Stem Cells. World Journal of Stem Cells, vol. 2014, no. 26, hlm. 552-562.

Lee, R.H., Pulin, A.A., Seo, M.J., Kota, D.J., Ylostalo, J., Larson, B.L., Prieto, L.S., Delafontaine, P., Prockop, D.J. 2009. Intravenous hMSCs Improve Myocardial Infarction in Mice Because Cells Embolized in Lung Are Activated to Secrete the Anti-Inflammatory Protein TSG-6. Cell Stem Cell, vol. 5, no. 1, hlm. 54 - 63.

Liang, J., Zhang, H., Hua, B., Wang, H., Lu, L., Shi, S., Hou, Y., Zeng, X., Gilkeson, G.S., Sun, L. 2010. Allogenic Mesenchymal Stem Cell Transplantation in Refractory Systemic Lupus Erythematosus : A Pilot Clinical Study. Annals of the Rheumatic Disease, vol. 2010, no. 69, hlm. 1423-1429.

Madrigal, M., Rao, K.S., Riordan, N.H. 2014. A Review of Therapeutic Effects of Mesenchymal Stem Cell Secretions and Induction of Secretory Modification by Different Culture Methods. Journal of Translational Medicine, vol. 12, no. 260, hlm. 1-14.

Meirelles, L.D.S., Fontes, A.M., Covas, D.T., Caplan, A.I. 2009. Mechanism Involved in the Therapeutic Properties of Mesenchymal Stem Cells. Cytokine Growth Factor Review, vol. 2009, no. 20, hlm. 419-427.

Mok, C.C., Birmingham, D.J., Ho, L.Y., Hebert, L.A., Rovin, B.H. 2013. High Sensitivity C-Reactive Protein, Disease Activity and Cardiovascular Risk Factors in Systemic Lupus erythematosus. Arthritis Care \& Research, vol. 65, no. 3, hlm. 441-447.

Mok, C.C. dan Lau, C.S. 2003. Pathogenesis of Systemic Lupus Erythematosus. Journal of Clinical Pathology, vol. 2003, no. 56, hlm. 481-490.

Musai, M. 2010. Terapi Lupus Eritematosus Sistemik dengan Penghambatan Kostimulasi Sel T. Majalah Kedokteran Indonesia, vol. 60, no. 10, hlm. 1-6.

Okunishi, K., Dohi, M., Fujio, K., Nakagome, K., Tabata, Y., Okasora, T., Seki, M., Shibuya, M., Imamura, M., Harada, H., Tanaka, R., Yamamoto, K. 2007. Hepatocyte Growth Factor Significantly Suppresses Collagen-Induced Arthritis in Mice. The Journal of Immunology, vol. 2007, no. 179, hlm. 5504-5513. 
Perhimpunan Reumatologi Indonesia. 2011. Rekomendasi Perhimpunan Reumatologi Indonesia Untuk Diagnosis dan Pengelolaan Lupus Eritematosus Sistemik. Perhimpunan Reumatologi Indonesia.

Perry, D., Sang, A., Yin, Y., Zheng, Y.Y., Morel, L. 2010. Murine Models of Systemic Lupus Erythematosus. Journal of Biomedicine and Biotechnology, vol. 2011, hlm. 1-20.

Postal, M., Costallat, L.T. dan Appenzeller, S. 2012. Biological Therapy in Systemic Lupus Erythematosus. International Journal of Rheumatology, vol. 2012, hlm.1-9.

Rezaieyazdi, Z., Sahebari, M., Hatef, M.R., Abbasi, B., Rafatpanah, H., Afshari, J.T., Esmaily, H. 2011. Is There Any Corelation Between High Sebsitive CRP and Disease Activity in Systemic Lupus Erythematosus?. Lupus, vo. 2011, no. 20, hlm. 1494-1500.

Reeves, W.H., Lee, P.Y., Weinstein, J.S., Satoh, M., Lu, L. 2009. Induction of Autoimmunity by Pristane and Other Naturally Occurring Hydrocarbons. Trends in Immunology, vol. 30, no. 9, hlm. 455-464.

Song, M., Heo, J., Chun, J.Y., Bae, H.S., Kang, J.W., Kang, H. 2014. The Paracrine Effects of Mesenchymal Stem Cells Stimulate the Regeneration Capacity of Endogenous Stem Cells in the Repair of a Bladder Outlet Obstruction Induced Overactive Bladder. Stem Cells Reviews, vol. 23 , no. 6 , hlm. $654-663$.

Suarjana, I.N. 2014. Imunopatogenesis Lupus Eritematosus Sistemik, hlm. 3331-3345. dalam : Simadibrata M., Syam A.F., Setiati S., Setyohadi B., Alwi I (edt). Buku Ajar Ilmu Penyakit Dalam Jilid III. Edisi VI. Interna Publishing FK UI, Jakarta.

Sun, L., Wang, D., Liang, J., Zhang, H., Feng, X., Wang, H. 2010. Umbilical Cord Mesenchymal Stem Cell Transplantation in Severe and Refractory Systemis Lupus Erythematosus. Arthritis \& Rheumatism, vol. 62, no. 8, hlm. 2467-2475.

Yang, C.C., Shih, Y.H., Ko, M.H., Hsu, S.Y., Cheng, H., Fu, Y.S. 2008. Transplantation of Human Umbilical Mesenchymal Stem Cells from Wharton's Jelly After Complete Transection of the Rat Spinal Cord. PloS one, vol. 3, issue 10, hlm. 1-11.

Yap, D.Y.H. dan Lai, K.N. 2010. Cytokines and Their Roles in Pathogenesis of Systemic Lupus Erythematosus: From Basics to Recent Advances. Journal of Biomedicine and Biotechnology, vol. 2010, hlm. 1-10. 